RUNNING TITLE: Carbon/nitrogen remobilization during alfalfa regrowth

\title{
Effect of shoot removal on remobilization of carbon and nitrogen during regrowth of nitrogen-fixing alfalfa
}

\author{
Iker Aranjuelo ${ }^{1,2}$, Gemma Molero ${ }^{2,3}$, Gorka Erice ${ }^{4}$, Joseba Aldasoro ${ }^{5}$, Cesar \\ Arrese-Igor $^{5}$ and Salvador Nogués ${ }^{2}$ \\ ${ }^{1}$ Instituto de Agrobiotecnología (IdAB), Universidad Pública de Navarra-CSIC- \\ Gobierno de Navarra, Campus de Arrosadía, E-31192-Mutilva Baja, Spain. \\ ${ }^{2}$ Unitat de Fisologia Vegetal, Facultat de Biologia, Universitat de Barcelona, Diagonal \\ 645, 08028, Barcelona, Spain \\ ${ }^{3}$ International Maize and Wheat Improvement Center (CIMMYT), El Batán, Texcoco, \\ CP 56130, Mexico. \\ ${ }^{4}$ Departamento de Biología Vegetal, Sección Biología Vegetal (Unidad Asociada al \\ CSIC, EEAD, Zaragoza e ICVV, Logroño), Facultades de Ciencias y Farmacia, \\ Universidad de Navarra, c/Irunlarrea 1, E-31008 Pamplona, Navarra, Spain. \\ ${ }^{5}$ Dpto. Ciencias del Medio Natural, Universidad Pública de Navarra Campus de \\ Arrosadía, E-31006-Pamplona, Spain.
}

Corresponding author e-mail: iker.aranjuelo@unavarra.es 


\section{Abstract}

The contribution of carbon and nitrogen reserves to regrowth following shoot removal and the processes involved in the reduction of nodule functioning were studied in alfalfa plants (Medicago sativa L.). To do so, isotopic labelling was conducted at root and canopy level with both ${ }^{15} \mathrm{~N}_{2}$ and ${ }^{13} \mathrm{C}$-depleted $\mathrm{CO}_{2}$ on exclusively nitrogen fixing alfalfa plants. Our results indicate that the roots were the main sink organs before shoot removal as expected. Seven days after regrowth the carbon and nitrogen stored in the roots was invested in shoot biomass formation and partitioned to the nodules in order to sustain respiratory activity. However, this carbon and nitrogen derived from the root did not overcome carbon and nitrogen limitation in nodules and leaves. Together with the limited carbohydrate availability, the up-regulation of nodule peroxidases indicates the involvement of oxidative stress in a worse nodule performance. Fourteen days after shoot removal, leaf and nodule performance were completely reestablished.

Abbreviations: Aa, amino acid; An, light-saturated rate of net $\mathrm{CO}_{2}$ assimilation; $\mathrm{C}_{c}$, intracellular $\mathrm{CO}_{2}$ mole fraction; Cnew labeled C; Gluc, glucose; $g_{\mathrm{m}}$, mesophyll conductance; Fruc, fructose; $\mathrm{F}_{\mathrm{v}} / \mathrm{F}_{\mathrm{m}}$, maximum quantum yield of PSII photochemistry; $\mathrm{J}_{\max }$, the maximum electron transport rate contributing to RuBP regeneration; Nase, nitrogenise; Nnew, labeled N; PEPc, phosphoenolpyruvate carboxylase PPFD, photon flux density; Rleaf, leaf dark respiration; ROS, reactive oxygen species; Rnodule, nodule dark respiration, Rroot, root dark respiration; TOM, Total organic matter; T0, shoot removal day; T7, 7 days after shoot removal; T14, 14 days after shoot removal; TSP, total soluble protein; Vcmax, maximum carboxylation velocity of Rubisco; VSP, vegetative storage protein; $\delta^{13} \mathrm{C}$ isotopic composition; $\delta^{15} \mathrm{~N}$ isotopic composition; $\Delta^{13} \mathrm{C}$, carbon isotope discrimination

Key words: Alfalfa, regrowth, N/C remobilization, nodule, proteomic 


\section{Introduction}

Forage crops are subjected to regular shoot removal. During vegetative growth, shoots are the source organs providing photosynthates to young developing shoots, roots and nodules, which are the main carbon sink organs. However, total or partial removal of the photosynthetic area requires the mobilisation of carbon and nitrogen reserves from roots to shoots (Avice et al. 2003) generating an inversion of source and sink organs. After shoot removal, regrowth of the new shoot in alfalfa plants (Medicago sativa) is supported by non-structural carbohydrates along with nitrogen compounds (such as proteins and amino acids) stored in the taproots (Gramshaw et al. 1993, Volenec et al. 1996, Avice et al. 1997, Dhont et al., 2002 and 2006, Pembleton et al. 2010). During regrowth period, these non-structural carbohydrates are used to support respiration of the crown and taproots until photosynthesis is re-established. Although a larger reduction in non-structural carbohydrates in comparison with nitrogen root reserves has been observed (Kim et al. 1993), regrowth is linked with nitrogen reserves in roots rather than carbon reserves (Ourry et al. 1994, Corre et al. 1996, Meuriot et al. 2004, Pembleton et al. 2010). This is also supported by the fact that initial root and crown starch content are not determining regrowth yield (Ourry et al. 1994, Avice et al. 1996). In a previous study conducted with alfalfa plants labelled with ${ }^{13} \mathrm{CO}_{2}$ and ${ }^{15} \mathrm{NH}_{4}{ }^{15} \mathrm{NO}_{3}$, $80 \%$ of nitrogen and only $6 \%$ of carbon were mobilised from root and crown reserves in growing shoots of alfalfa whereas about $40 \%$ of initial carbon was used for root respiration eight days after shoot removal (Avice et al. 1996). Recent studies have described that during early regrowth, about $50 \%$ of total nitrogen in roots and crowns are mobilised to meet the nitrogen demand of shoots (Erice et al. 2011). These studies highlight the importance of nitrogen compounds to support regrowth after a shoot removal event.

Alfalfa plants obtain nitrogen compounds from the soil or through the symbiotic relationship established with nitrogen fixing bacteria plants. The symbiotic relationship between the plant and bacteria takes place in the root nodules. Within this symbiotic relationship, the plant provides photoassimilates, which supply the energy and carbon skeletons required by the bacteroid to fix nitrogen by nitrogenase ( $\mathrm{N}_{\text {ase }}$ ). Photoassimilates are delivered to the nodules as sucrose through the phloem where it is transformed into dicarboxylic acids, mainly in the form of malate and succinate (Lodwig et al. 2003). Organic acids provide reductant to both the $N_{\text {ase }}$ complex and the 
respiratory chain that fuels $\mathrm{N}_{\text {ase }}$ with the ATP necessary for nitrogen fixation (Kouchi and Yoneyama 1986, Streeter 1987). The bacteroid returns ammonium $\left(\mathrm{NH}_{4}{ }^{+}\right)$to the host that is assimilated in the form of amino acids that are partitioned to the rest of the plant through the xylem according to their requirements (Udvardi and Day 1997, Molero et al. 2011). Previous studies show that, after shoots are removed, nodule functioning is reduced during the first days of regrowth (Boucaud and Bigot 1989, Ta et al. 1990) being concomitant with a decrease of $88 \%$ in nitrogen fixation, $24 \mathrm{~h}$ after clipping (Vance et al. 1979). However, the processes involved in the reduction of nodule functioning during shoot removal remain, so far, unclear. Previous studies conducted in nitrogen fixing alfalfa plants exposed to other stressful growth conditions highlight different processes that are limiting nodule functioning such as: (i) carbohydrate availability, (ii) accumulation of nitrogenous compounds, (iii) $\mathrm{O}_{2}$ permeability, and (iv) accumulation of reactive oxygen species (ROS) (Arrese-Igor et al. 1999, Naya et al. 2007, Becana et al. 2010, Aranjuelo et al. 2011, 2013). Some of these mechanisms could also been involved in the reduction of nodule functioning after shoot removal and have been considered in the present study.

Although carbon/nitrogen/ $\mathrm{N}$ remobilization has been previously described in $\mathrm{N}_{2}$ fixing plants after shoot removal (Kim et al. 1993, Avice et al. 1996, Corre et al. 1996), those studies have been mainly focused in the remobilization of root derived nitrogen and carbon, paying scarce attention to nodule performance and its role during regrowth period. Another aspect to consider is that, in these studies, ${ }^{15} \mathrm{~N}$ was provided as ${ }^{15} \mathrm{NO}_{3}^{-}$ and/or ${ }^{15} \mathrm{NH}^{+}{ }_{4}$ in the nutrient solution and not as a gas $\left({ }^{15} \mathrm{~N}_{2}\right)$, which is the nitrogenase substrate. This means that labelled nitrogen was firstly absorbed by the root and not fixed directly by the nodule. This is a relevant aspect because inorganic nitrogen supply inhibits nitrogen fixation by the nodule (Arrese-Igor et al. 1997). In this sense, the influence of shoot removal on nodule functioning and metabolite exchange between the nodule and other plant organs remain unclear. Within this context, the main goals of our study were to (i) characterise in detail the effect of shoot removal on nodule functioning and (ii) to study its implication in root carbon and nitrogen remobilization during regrowth in exclusively nitrogen fixing alfalfa plants. For this purpose, metabolic, proteomic and physiological characterisation of plants and nodules were performed. An isotopic labelling was conducted with both ${ }^{15} \mathrm{~N}_{2}$ and ${ }^{13} \mathrm{C}$-depleted $\mathrm{CO}_{2}$ on alfalfa plants grown under controlled conditions and we took advantage of isotope ratio mass 
spectrometry to investigate the carbon and nitrogen fixation and remobilization during the regrowth period.

\section{Material and Methods}

\section{Experimental design and determinations}

Seeds of alfalfa (Magali cv.) were germinated on petri dishes. After 3-4 days, seedlings were transplanted into 7L white plastic pots filled with sand and grown in a greenhouse at $25 / 15^{\circ} \mathrm{C}$ (light/dark) with a photoperiod of 16 hours under natural daylight. During the first month, plants were inoculated three times with Rhizobium meliloti strain 102F78. Plants were watered twice a week with Hoagland nitrogen free solution and once a week with deionised water to avoid salt accumulation in pots. Eighty days after sowing, the plants were transferred to a growth chamber (Conviron E15, Controlled Environments Ltd., Winnipeg, Canada) where the double ${ }^{12} \mathrm{CO}_{2} /{ }^{15} \mathrm{~N}_{2}$ labelling was conducted for 10 days. Once the labelling was concluded, three plants were dissected into leaves, stems, roots and nodules (T0) and were immediately frozen in liquid nitrogen and stored at $-80^{\circ} \mathrm{C}$. Gas exchange measurements were performed and then, the aerial part of all the plants in the chamber was clipped. When the plants were 97 (T7) and 104 (T14) days old, gas exchange determinations, together with leaf, stem, root and nodule sampling were carried out following the protocols described below. Once the samplings were completed, all the material was grounded with liquid nitrogen and stored at $-80^{\circ} \mathrm{C}$ until further use.

\section{Carbon and nitrogen labelling}

Plants were randomly divided into two groups: half of the plants were placed in one chamber maintained at ambient carbon and nitrogen isotopic composition $\left(\delta^{13} \mathrm{C}\right.$ and $\delta^{15} \mathrm{~N}$ respectively), whereas the other half were placed within the second chamber where $\delta^{13} \mathrm{C}$ and $\delta^{15} \mathrm{~N}$ was modified. Carbon and nitrogen labelling were carried out for a period of ten days. For carbon labelling, we took advantage of the typical ${ }^{13} \mathrm{C}$-depletion in industrial $\mathrm{CO}_{2}$ as compared with ambient air and thus we conducted a ${ }^{12} \mathrm{C}$-labelling. We mixed industrial $\mathrm{CO}_{2}\left(\delta^{13} \mathrm{C}=-38.2 \%\right.$; Carburos Metálicos SA, Barcelona, Spain) with ambient air $\left(\delta^{13} \mathrm{C}=-12.5 \%\right.$ ) to yield a $\delta^{13} \mathrm{C}$ value of $-22.6 \%$ inside the growth cabinet. Control plants (non-labelled) were grown in a second growth cabinet maintained under ambient conditions $(-12.5 \%)$.

Comentario [MG3]: No necessary to include

Comentario [MG4]: It seems contradictory as nutrient full would include $\mathrm{N}$...just with Hoagland is fine

Comentario [MG5]: Avoid the '=' to be consistent with below

Comentario [MG6]: This is necessary to understand below

Comentario [MG7]: Not necessary 
Fornitrogen labelling, we used $5 \%{ }^{15} \mathrm{~N}_{2}$ (prepared from 99 atom $\%{ }^{15} \mathrm{~N}_{2}$ excess, EurisoTop, Saint-Aubin, France). Labelled $\mathrm{N}_{2}$ was injected to a handmade chamber attached to the pots using gas syringes (SGE International Pty Ltd, Ringwood, Vic., Australia). Control plants were also injected with nitrogen from a bottle with natural isotopic composition of nitrogen $\left(\delta^{15} \mathrm{~N}=0 \%\right.$ ). Two injections were undertaken every day at 10 am and at $12 \mathrm{pm}$. This lead to an average $\delta^{15} \mathrm{~N}$ value inside the labelling chamber of $+112 \%$. Once the labelling was finished, the Conviron chambers were opened and quickly purged with ambient air. The shoots were clipped and the plant was harvested as described above.

\section{Carbon and nitrogen isotope and content analysis of TOM}

A subsample of frozen and grounded material was dried at $60^{\circ} \mathrm{C}$ over $48 \mathrm{~h}$ and was weighed in small tin capsules in order to conduct analysis in total organic matter (TOM). Samples were analysed to determine the carbon and nitrogen isotope composition using a Flash 1112 Elemental Analyzer (Carbo Erba, Milan) coupled to an IRMS Delta C isotope ratio mass spectrometer through a Conflo III Interface (ThermoFinnigan, Germany).

Results of carbon isotope ratio analyses are reported in per mile (\%) on the relative $\delta$ scale, as $\delta^{13} \mathrm{C}$ and refer to the international standard V-PDB (Vienna Pee Dee Belemnite) according to the following equation:

$$
\delta^{13} \mathrm{C}=\left(\frac{R_{\text {sample }}}{R_{\text {standard }}}\right)-1
$$

where $R$ is the ${ }^{13} \mathrm{C} /{ }^{12} \mathrm{C}$ ratio.

Carbon isotope discrimination $\left(\Delta^{13} \mathrm{C}\right)$ of shoot TOM was calculated from $\delta_{\mathrm{a}}$ and $\delta_{\mathrm{p}}$ (Farquhar et al. 1980) as:

$$
\Delta^{13} C=\frac{\delta_{a}-\delta_{p}}{\delta_{p}+1}
$$

Where $a$ and $p$ refer to air and plant, respectively. 
Nitrogen results were also expressed in $\delta$ notation $\left(\delta^{15} \mathrm{~N}\right)$ using international secondary standards of known ${ }^{15} \mathrm{~N} /{ }^{14} \mathrm{~N}$ ratios (IAEA $\mathrm{N}_{1}$ and IAEA $\mathrm{N}_{2}$ ammonium sulphate and IAEA $\mathrm{NO}_{3}$ potassium nitrate) referred to $\mathrm{N}_{2}$ in air:

$$
\delta^{15} \mathrm{~N}=\left(\frac{R_{\text {sample }}}{R_{\text {standard }}}\right)-1
$$

where $R$ is the ${ }^{15} \mathrm{~N} /{ }^{14} \mathrm{~N}$ ratio.

Nitrogen and carbon content were determined from three replicates at the Serveis Cientifico-Técnics of the University of Barcelona (Barcelona, Spain) using an elemental analyzer (EA1108, Series 1; Carbo Erba Instrumentazione, Milan, Italy).

\section{Isotopic composition of respired $\mathrm{CO}_{2}$}

Isotopic composition of respired $\mathrm{CO}_{2}$ was analysed as previously described by Nogués et al. (2004). Leaves, primary roots and nodules were placed separately in a gas analysis chamber connected in parallel to the sample air hose of a LI-6400 (LI-COR, Lincoln, $\mathrm{NE}$ ). To accumulate $\mathrm{CO}_{2}$ for the $\delta^{13} \mathrm{C}$ analyses, leaves were analysed before harvesting. In the case of primary roots and nodules, the samples were cleaned, and immediately placed on a humid paper inside the chamber. $\mathrm{CO}_{2}$ respired by the plant was monitored by the Li-6400 so as to determine respiration rates. According to respiration rates, the time required to reach $\sim 300 \mu \mathrm{mol} \mathrm{mol}{ }^{-1} \mathrm{CO}_{2}$ (minimal mole fraction for an isotopic analysis) was calculated. Then, the chamber was flushed with $\mathrm{CO}_{2}$-free air, closed and the respired $\mathrm{CO}_{2}$ was accumulated. $\mathrm{CO}_{2}$ samples were collected with a 50 -mL syringe (SGE, Ringwood, Vic., Australia) and immediately injected into a 10-mL BD vacutainer, being passed through magnesium perchlorate that removed water vapour. To avoid contamination by ambient $\mathrm{CO}_{2}$ within the syringe and the needle, both were purged with pure nitrogen before each sampling. Vacutainers were also slightly overpressurised with pure N2 to avoid retro-diffusion of ambient $\mathrm{CO} 2$ into the syringe (Aranjuelo et al. 2009).

All the GC-MS, GC-C-IRMS and EA/IRMS analyses were performed at the the Serveis Cientifico-Técnics of the University of Barcelona. 
Calculations of the percentage of new carbon and new nitrogen in respired $\mathrm{CO}_{2}$ and TOM

The proportion of 'new' carbon (derived from the labelling) in $\mathrm{CO}_{2}$ respired in darkness after illumination and 'new' carbon and nitrogen in TOM was calculated following Nogués et al. (2004):

$$
x=100 \times \frac{\delta Y^{\prime}-\delta Y}{\left(\delta_{o}-\Delta Y-\delta Y\right)}
$$

where $\delta Y^{\prime}$ and $\delta Y$ are the carbon or nitrogen isotope compositions from labelled and control plants, respectively; $\delta_{o}$ is the isotope composition of the outlet air and $\Delta Y$ is the isotopic discrimination calculated with Eq. (2).

\section{Metabolic compound determinations}

Leaf extracts were homogenised in $80 \%$ ethanol (v/v) and were sonicated for $25 \mathrm{~min}$. at $30{ }^{\circ} \mathrm{C}$ using an Ultrasons-H ultrasonic bath (Selecta, Spain). The hydroalcoholic phase was evaporated through a Turbovap evaporator (Zymark, Carmel, IN, USA) and resuspended with $4 \mathrm{~mL}$ of distilled water. The sample was centrifuged at $2.300 \mathrm{~g}$ for 10 minutes and the supernatant and the pellet were stored separately at $-80^{\circ} \mathrm{C}$.

Soluble sugar, starch and organic acid content

Sucrose, glucose (Gluc) and fructose (Fru) content were determined in the supernatant fraction with a Beckman P/ACE5500 capillary electrophoresis system (Beckman Instruments, Fullerton, CA, USA) (Marino et al. 2006). Starch content was determined in the pellet according to Ethier and Livingston (2004).

The organic acid extraction protocol was as described by Gálvez et al. (2005). The extracts were filtered with Milex filters (Millipore, Billerica, MA, USA) and injected in a DX-500 ion chromatograph equipped with an IonPac AS11 column connected to an ATC-1 protecting column and an AG11 precolumn (all chromatography equipment from Dionex, Salt Lake City, UT, USA).

\section{Amino acid content}


Leaf fresh material was exhaustively extracted in boiling $80 \%$ (v/v) ethanol. Ethanolsoluble extracts were dried in a Turbovap LV evaporator (Zymark Corp, Hopkinton, MA, USA) and soluble compounds were re-dissolved with $4 \mathrm{ml}$ of distilled water, and mixed and centrifuged at $20000 \mathrm{~g}$ for $10 \mathrm{~min}$. Free amino acids were assayed using the acid ninhydrin method of (Yemm and Cooking et al., 1955).

\section{Gas exchange determinations}

Fully expanded flag leaves were enclosed in a Li-Cor 6400 gas exchange portable system (Li-Cor, Lincoln, Nebraska, USA). Determinations were conducted on healthy and leaves at photosynthetic photon flux density (PPFD) of $1200 \mu \mathrm{mol} \mathrm{m} \mathrm{m}^{-2} \mathrm{~s}^{-1}$, at $25^{\circ} \mathrm{C}$. The gas exchange response to $\left[\mathrm{CO}_{2}\right]$ was measured from 0 to $1200 \mu \mathrm{mol} \mathrm{mol}^{-1}$. The light-saturated rate of $\mathrm{CO}_{2}$ net assimilation $\left(\mathrm{A}_{\mathrm{n}}\right)$ was calculated using equations developed by von Caemmerer and Farquhar (1981) as described by Pons et al. (2009). Mesophyll conductance $\left(g_{\mathrm{m}}\right)$ was determined according Pons et al. (2009) and Long and Bernacchi (2003). The intracellular $\mathrm{CO}_{2}$ mole fraction $\left(\mathrm{C}_{\mathrm{c}}\right)$ was determined according to Long and Bernacchi. (2003). Nodule and root respiration were obtained using an external cuvette connected in parallel to the sample air hose of the Li-Cor 6400 (Nogués et al. 2004). Plants were dark-adapted for 30 minutes before dark respiration $\left(R_{D}\right)$ measurements (Nogués et al. 2004). Estimations of the maximum carboxylation velocity of Rubisco $\left(\mathrm{Vc}_{\max }\right)$ and the maximum electron transport rate contributing to RuBP regeneration $\left(\mathrm{J}_{\max }\right)$ were made using the method of Ethier and Livingston (2004).

Fluorescence parameters were measured with a fluorescence chamber (LFC 6400-40; Li-COR) coupled to the Li-Cor 6400. Light-adapted variables included maximum photochemical efficiency \photosystem II $\left(\mathrm{Fv}_{\mathrm{v}} / \mathrm{Fm}\right)$.

\section{Two-dimensional difference gel electrophoresis}

Nodule and leaf samples (200 mg FW) were ground in a mortar using liquid nitrogen and re-suspended in $2 \mathrm{~mL}$ of cold acetone containing 10\% TCA. After centrifugation at $16,000 \mathrm{~g}$ for $3 \mathrm{~min}$ at $4{ }^{\circ} \mathrm{C}$, the supernatant was discarded and the pellet was rinsed successively with methanol, acetone, and phenol solutions as previously described by Aranjuelo et al. (2011). The pellet was stored at $-20^{\circ} \mathrm{C}$ or immediately re-suspended in $200 \mu \mathrm{L}$ of R2D2 rehydratation buffer [5 M urea, $2 \mathrm{M}$ thiourea, 2\% 3-[(3-

Comentario [MG12]: IKER, FALTA PONER COMO SE CALCULO LA CONDUCTANCIA DEL MESOFILO, gm...SEGÚN YO ES gs

(CONDUCTANCIA ESTOMATICA) PERO EN LA TABLA 2 APARECE COMO LA CONDUCTANCIA DEL MESOFIL 
cholamidopropyl) dimethyl-ammonio]-1-propanesulphonate, $2 \% \quad \mathrm{~N}$-decyl-N,Ndimethyl-3-ammonio-1-propanesulphonate, $20 \mathrm{mM}$ dithiothreitol, $5 \mathrm{mM}$ TRIS (2carboxyethyl) phosphine, 0.5\% IPG buffer [(GE Healthcare, Saclay, France), pH 4 to 7] (Mechin et al., 2003). Total soluble protein (TSP) concentration was determined with the method of Bradford (Bradford, 1976) using BSA as a standard. Samples were cuploaded in IPG strips, $24 \mathrm{~cm}, \mathrm{pH}$ 3-11NL (GE Healthcare), and subjected to isoelectrofocusing in an IPGphor ${ }^{\mathrm{TM}}$ IEF System (GE Healthcare) according to the manufacturer's recommendations. Upon completion of the first dimension, strips were incubated in an equilibration buffer (50 mM Tris- $\mathrm{HCl}, \mathrm{pH}$ 8.8, $6 \mathrm{M}$ urea, 30\% glycerol, 2\% SDS, a trace of bromophenol blue), containing 0.5\% DTT for $15 \mathrm{~min}$ and thereafter in the same buffer containing 4.5\% iodoacetamide for $15 \mathrm{~min}$. For the second dimension, strips were loaded onto 10 and $12 \%$ (for nodules and leaves respectively) polyacrylamide gels and run (1W/gel) for 12-14 h until the bromophenol blue dye reached the gel end. Proteins were visualised by staining with SYPRO Ruby Protein Gel Stain (Bio-Rad) and images were acquired with a Typhoon ${ }^{\mathrm{TM}}$ Trio Imager (GE Healthcare). Spots differentially represented were excised manually and gel specimens were processed with a MassPrep station (Waters). In-gel tryptic digestion was performed with $12.5 \mathrm{ng} / \mu \mathrm{l}$ trypsin in $50 \mathrm{mM}$ ammonium bicarbonate for $12 \mathrm{~h}$ at $37^{\circ} \mathrm{C}$. The resulting peptides were extracted with 1\% formic acid and 50\% acetonitrile. The 2D gels were analyzed using PDQuest 8 software (Bio-Rad, Hercules, CA, USA). After the automated detection and matching, manual editing and normalization were carried out. Three well-separated gels of each sample were used to create "replicate groups". Statistic sets, quantitative and qualitative, were created within experimental groups. These sets were analyzed using the Student's $t$-test with the significance level of 95\%. In the quantitative sets, the upper limit and the lower limit were set to 4 and 0.25 , respectively. Then, the Boolean analysis of sets were carried out for both the quantitative and qualitative sets. The spots from the Boolean sets were compared among three biological replicates. Only spots displaying reproducible changes were considered to be differentially-expressed proteins. The $\mathrm{Mr}$ of the proteins on gels was determined using standard protein markers and $p \mathrm{I}$ was determined by the migration of protein spots along the $18 \mathrm{~cm}$ IPG strips (4-7 linear).

\section{Statistical analyses}


Statistical analysis was performed by the analysis of variance ANOVA (SPSS v.12.0; SPSS Inc., Chicago, IL, USA). Analysed organs and harvests were used as the two factors. The results were accepted as significant at $\mathrm{P}<0.05$. When differences between harvests and/or organs and/or interactions were significant according to ANOVA, least significant differences were evaluated using the Least Significant Difference post hoc test (Tukey b) $(\mathrm{P}<0.05)$.

\section{Results}

At the end of the labelling period (T0), roots and nodules had the highest amounts of labelled carbon andnitrogen ( $\mathrm{C}_{\text {new }}$ and $\mathrm{N}_{\text {new }}$ respectively) in total organic matter (Fig. $1 \mathrm{~A}, 1 \mathrm{~B}) . \mathrm{C}_{\text {new }}$ and $\mathrm{N}_{\text {new }}$ were uncoupled in apical leaves and stems where high $\mathrm{C}_{\text {new }}$ values and comparatively low $\mathrm{N}_{\text {new }}$ sink strengths were detected. Seven days after clipping the shoots (T7), $\mathrm{C}_{\text {new }}$ represented around $60 \%$ of carbon present in leaves, roots and nodules (Fig. 1A). On the other hand, the diminishment in root $\mathrm{N}_{\text {new }}$ was counteracted by its increase in nodules and leaves. Seven days later (T14), even if in leaves and nodules $\mathrm{C}_{\text {new }}$ was similar in leaves and roots, the availability of labelled $\mathrm{C}$ diminished in nodules (Fig. 1A). In the case of $N_{\text {new }}$, it decreased in all the organs. The $\delta^{13} \mathrm{C}$ analyses of respired $\mathrm{CO}_{2}\left(\delta^{13} \mathrm{CO}_{2}\right)$ indicated that at $\mathrm{T} 0,80 \%$ of the $\mathrm{CO}_{2}$ respired by roots and nodules was composed of labelled C (Fig. 1C), whereas in leaves this values was lower (i.e. $60 \%$ ). $\delta^{13} \mathrm{CO}_{2}$ also showed that $\mathrm{C}_{\text {new }}$ decreased progressively in roots, nodules and leaves.

The $\mathrm{C}_{\text {new }}$ and $\mathrm{N}_{\text {new }}$ of the total soluble protein (TSP) indicated that at T0, roots showed the largest labelled carbon and nitrogen sink strength (Fig. 2A, 2B). Although availability of labelled carbon and nitrogen in roots at T7 was not significantly modified, $\mathrm{C}_{\text {new }}$ and $\mathrm{N}_{\text {new }}$ content had increased in leaves. Interestingly, at $\mathrm{T} 14$, roots were the organs where $\mathrm{N}_{\text {new }}$ decreased to the largest extent, whereas in leaves, depletion of $\mathrm{C}_{\text {new }}$ availability was more marked (Fig. 2A, 2B).

Gas exchange analyses revealed that the lowest leaf photosynthetic rates $\left(A_{n}\right)$ were detected 7 days after shoot removal, with no differences observed between T0 and T14 (Table 1). No significant differences were detected in Rubisco carboxylation maximum capacity $\left(\mathrm{Vc}_{\max }\right)$ or $\mathrm{RuBP}$ regeneration maximum capacity $\left(\mathrm{J}_{\max }\right)$ between the different harvests. The lower mesophyll conductance $\left(\mathrm{g}_{\mathrm{m}}\right)$ and chloroplastic $\mathrm{CO}_{2}$ content $\left(\mathrm{C}_{\mathrm{c}}\right)$ at

Comentario [MG13]: =Iker please change the tables, see the file I send

Comentario [MG14]: Mesophyll conductance or stomatal conductance??? Comentario [MG15]: Chloroplastic content or internatl content $(\mathrm{Ci})$ ?? 
T7 pointed out limitations in $\mathrm{CO}_{2}$ diffusion as being responsible for the lower $\mathrm{A}_{n}$ in these plants (Table 1). Dark respiration (R) was not affected in nodules, roots and leaves. No significant differences were observed in the maximal photochemical efficiency $\left(\mathrm{F}_{\mathrm{v}} / \mathrm{F}_{\mathrm{m}}\right)$ between the 3 harvests (Table 1$)$.

Carbohydrate analyses showed that sucrose, fructose and starch were the compounds with the greatest decrease in nodules, roots and leaves where glucose was not affected by shoot removal (Table 2). Only sucrose levels in the roots were completely recovered 14 days after shoot removal while fructose and starch levels were not recovered in roots and nodules.

Organic acid levels were differentially affected in the organs by shoot removal and days after clipping (Table 3 ). Whereas the malate and $\alpha$-ketoglutarate contents diminished at T7 and were restored at T14, oxalacetate levels were not modified in the nodules. Nodule succinate decreased at T7 and at T14 the levels were not restored. In the case of citrate, although there were no significant differences at T7, at T14 it was depleted. In roots, malate (and $\alpha$-ketoglutarate to lesser extent) content progressively increased at T7 and T14 (Table 3) while oxalacetate and citrate were depleted at T7 and T14. Organic acids in the leaves showed no change ( $\alpha$-ketoglutarate and succinate) or an increase (malate and citrate) at T7 and T14 (Table 3).

Nitrogen content analyses showed that its availability increased in nodules, 7 and 14 days after shoot removal (Table 4). In the other hand, in case of roots nitrogen content decreased (compared with T0) at T7 and T14. As it is shown in Table 4, with the exception of roots (where its contents decreased), shoot removal had no significant effect in carbon content. No significant differences were detected in nodule and leaf total soluble protein (TSP) levels in the different harvests whereas a decrease in root TSP at T7 and T14 was observed (Table 4). Amino acid (Aa) content displayed similar variations in the nodules and roots (Table 4). In both of these organs the largest values were reached at T7, whereas at T14 initial Aa values were maintained. In the case of leaves, no significant differences were observed at T7 and T14. The carbon/nitrogen ratio was also differentially affected by shoot removal, in the nodules, roots and leaves (Table 4). Regarding nodules, carbon/nitrogen decreased at T7 (compared with T0) and was maintained at T14. No changes were observed in the roots and an increase was observed in leaves (Table 4).
Comentario [MG16]: Iker, according to table 1 , there are not significant differences for respiration values in any organ

Comentario [MG17]: Glucose didn’t change 
The proteomic characterisation conducted in nodules indicates that at T7 (compared with T0), with the exception of elongation factor and cyclic AMP receptor proteins (whose content decreased), the proteins were up-regulated (Table 5). These proteins were classified into different groups according to their presumed biological function. The down-regulated proteins were classified as being involved in cell structure and energy. Among the up-regulated proteins, metabolism (1 protein), cell structure (2 proteins), disease/defence (4 proteins) and unknown (2 proteins) were detected. At T14, with two exceptions (involved in energy and disease/defence processes), the majority of proteins (9 in total) were up-regulated (Table 6). Among the up-regulated proteins, disease/defence (1 protein), symbiotic (2 proteins), cell structure (1 protein, energy (1 protein), metabolism (2 proteins) and one unknown protein were detected. Leaf protein profiles showed that compared with T0, 4 proteins were down-regulated at T7 (Table 7). More specifically, two proteins involved in energy processes, a protein involved in cell/structure functioning and one protein with unknown function. On the other hand, the up-regulated proteins comprised proteins involved in energy (3 proteins), metabolism (1 protein), and three proteins with unclassified function. At T14, only Rubisco was up-regulated. Among the down-regulated proteins, two were involved in energy processes, another one with disease/defence function and one with an unknown role were detected (Table 8).

\section{Discussion}

Nitrogen fixed in the nodules through nitrogenase activity is essential to support plant growth whereas photoassimilates are essential to sustain energy and carbon-skeletons required for nitrogen fixation and amino acid synthesis (Molero et al. 2014).However, the fact that 7 days after shoot removal, nodule sucrose, malate and $\alpha$-ketoglutarate content decreased (Tables 2 and 3) indicates that shoot removal reduced carbon availability affecting negatively nodule performance. . Interestingly, the increased presence of labelled carbon in nodules 7 days after clipping (and the end of labelling) highlighted that a portion of the carbon remobilized by the roots was partitioned toward nodules (Figure 1A). Although it is very likely that roots provided carbon compounds such as sucrose to sustain nodule functioning, the reduction in sucrose content (Table 2) together with the increase in amino acids (Table 4) indicates that part of this $\mathrm{C}_{\text {new }}$ 
reached the nodules in the form of amino acids. This is in agreement with previous studies that demonstrate how some amino acids are supplied by the plant to the bacteroid (Lodwig et al. 2003, Prell and Poole 2006). In the nodules, nitrogenase reductase content was up-regulated suggesting an attempt to overcome the reduced substrate availability (Table 5). In agreement with previous findings described in nitrogen fixing plants exposed to changing environmental conditions (Serraj et al. 1998, Schulze et al. 2004, Aranjuelo et al. 2011, 2013), the $66 \%$ increase in nodule amino acid content at $\mathrm{T} 7$ revealed that amino acid accumulation could contribute to the inhibition of $\mathrm{N}_{\text {ase }}$ activity (Hartwig et al., 1994, Serraj et al. 1998, 2001, King and Purcell 2005). Such accumulation of nitrogen compounds in nodules was originated from the reduced aboveground nitrogen demand (Serraj et al. 1998, Schulze et al. 2004, Aranjuelo et al. 2011, 2013). Although regrowing shoot is a nitrogen demanding organ, the low shoot biomass at T7 in comparison with pre-clipping biomass (data not shown) revealed thatnitrogen demand was strongly depleted.

Previous studies conducted in droughted nitrogen fixing alfalfa plants (Rubio et al. 2002, Naya et al. 2007, Becana et al. 2010) have indicated that the nodule respiration rate may increase the dissolved $\mathrm{O}_{2}$ mole fraction in bacteroids, thereby inhibiting $\mathrm{N}_{\text {ase }}$ and possibly causing oxidative stress. The strong up-regulation of two peroxidase isoforms (3.86 and 4.13 times) and wound-induced proteins (5.43 times) in nodules 7 days after regrowth, suggests that they were exposed to oxidative stress (Table 5). Reactive oxygen species (ROS), together with the decreased carbohydrate availability (Table 2) reveals that nitrogen fixation was inhibited at this stage. The lower nodule performance 7 days after clipping explained the fact that shoot biomass was mostly (72 $\%)$ constituted by pre-labelling nitrogen (Figure 1B????). Regarding the new aerial part, our study suggests that root derived a large proportion of $\mathrm{C}_{\text {new }}$ which was remobilized to the shoot. However, the remobilization of carbohydrate to leaves was not enough as for keeping soluble sugar levels similar to control plants (Table 2). Depleted Rubisco activase content (Table 7), together with the lower chloroplast $\mathrm{CO}_{2}$ (Table 2) highlight the fact that the photosynthetic activity of new leaves was reduced. Such inhibition made new leaves largely dependent on assimilates provided by roots. Furthermore, the lower availability of harpin binding proteins (disease resistance proteins)suggests that the leaves were subjected to stressful conditions.
Comentario [MG20]: Not necessary this detail

Comentario [MG21]: Iker, I don't see the correlation here....also cyclic AMP receptor is not involvein carbon

metabolism...or if so, it will be necessary to explain what does this protein do

Comentario [MG22]: Iker I don’t understand this sentence.... what is nitrogen reductase? Because I know nitrite or nitrate reductase....but I don't know wha do you refere...I think it would need a better explanation why the decrease in $\mathrm{C}$ increase nitrogen reductasa

Comentario [MG23]: We didn't measure nitrogenase...so we cannot say it as a fact

Comentario [MG24]: Where this number come from?

Comentario [MG25]: Is Cc or Ci?

Comentario [MG26]: Iker, usually in young leaves photosynthetic values are lower due to the leaves are still growing

Comentario [MG27]: Photoassimilates from the roots??? It seems that the roots do photosynthesis

Comentario [MG28]: I don't see the link, could you explain a little bit more? 
Due to the apparent nodule activity inhibition, the relevance of roots as a carbon and nitrogen source to sustain shoot growthis of great importance. The $20 \%$ diminishment in starch content confirmed carbon remobilization towards developing organs and to sustain respiration (Table 2). Although organic acid content decreased (i.e. succinate, oxalate, citrate) or was not affected (i.e. $\alpha$-ketoglutarate), the 5.76 fold increase in malate content indicated that the stimulation of the anaplerotic pathway fuelled the respiratory pathway. Similar results have been described in belowground organs of alfalfa under limited photoassimilate availability (Aranjuelo et al. 2013). As mentioned above, in alfalfa, endogenous nitrogen pools (mostly represented by amino acids and TSP) are largely used to support regrowth (Ourry et al. 1994, Avice et al. 1996, Barber et al. 1996). The fact that $\mathrm{N}_{\text {new }}$ and $\mathrm{C}_{\text {new }}$ availability was similar in root TSP showed that "old" nitrogen was remobilized in this organ to sustain shoot development (Figure 2). Nitrogen remobilization was confirmed by the 2.79 fold increase in root amino acid availability (Table 4) and the presence of $\mathrm{N}_{\text {new }}$ (Figure 1B).

The dilution in $\mathrm{N}_{\text {new }}$ content in nodules at T14 suggests that nodule performance was improved. The fact that cytosolic malate dehydrogenase and NifK nitrogenase contents were up-regulated (Table 6) highlighted that nitrogen fixation was restored 14 days after shoot removal. The increased leaf photosynthetic rates detected 14 days after clipping (Table 1) could contribute to the reestablishment of nodule functioning. Furthermore, the up-regulated availability of key proteins in the symbiotic relationship (Table 6), such as the putative leucine-binding protein, groEL (Radutoiu et al. 2003), confirmed improved nodule performance. Unlike the observations at T0 and T7, root isotopic composition 14 days after clipping highlighted that allocation of $\mathrm{N}_{\text {new }}$ throughout the plant was different from $\mathrm{C}_{\text {new. }}$. The $50 \%$ and $75 \%$ depletions in TOM and TSP $\mathrm{N}_{\text {new, }}$, respectively (Figures 1 and 2), were explained by the remobilization of nitrogen compounds towards shoots and the presence of nitrogen fixed during the post-labelling period. Depletion of $\mathrm{N}_{\text {new }}$ TSP in the roots revealed that protein-derived $\mathrm{N}$ remobilization contributed to shoot regrowth to a larger extent. Interestingly, root $\mathrm{C}_{\text {new }}$ did not significantly differ in TOM, in contrast with the observed for $\mathrm{N}_{\text {new }}$. Maintenance of root $\mathrm{C}_{\text {new }}$ from 7 to 14 days of regrowth implies that post labelling carbon assimilated contributed substantially to shoot formation in this period. The increased leaf photosynthetic rates, together with the increased sucrose content in leaves and especially in roots, would support this statement (Tables 1, 2). However, the $30 \%$ 
decrease in starch content would also reveal that pre-labelled carbon was also remobilized to sustain shoot growth. The large malate, $\alpha$-ketoglutarate and citrate content detected in roots (Table 3) explains that the depleted $\mathrm{C}_{\text {new }}$ in TOM was also explained by the fact that $\mathrm{C}_{\text {new }}$ was respired during this period.

As observed at the root level, improved nitrogen fixation, together with the increased photosynthetic rates, explained the dilution observed in $\mathrm{N}_{\text {new }}$ and $\mathrm{C}_{\text {new. }}$. Photosynthetic activity $\left(\mathrm{A}_{\mathrm{n}}\right)$ was larger (compared with T0) 14 days after clipping. $\mid$ The 12.60-fold increase in the Rubisco large subunit content (compared with T0) confirmed that the specific increase in Rubisco availability explained larger $A_{n}$ values of leaves 14 days after regrowth. The respective $50 \%$ and $67 \%$ depletions of $\mathrm{C}_{\text {new }}$ and $\mathrm{N}_{\text {new }}$ in TSP showed that proteins represented a major nitrogen and carbon sink of nitrogen and carbon assimilated during the post-labelling period. Furthermore, this fact together with the large increase in Rubisco content indicated that 7 to 14 days after shoot removal, Rubisco represented a major leaf nitrogen and carbon sink.

\section{Conclusions}

In summary, our study revealed the important implications of shoot removal in nodule, leaf and root performance during subsequent regrowth. This study revealed that shoot removal negatively affected the performance of nodules and newly formed leaves. Seven days after shoot clipping, root-derived carbon and nitrogen remobilization and partitioning towards nodules did not fulfil nodule carbohydrate requirements with a consequent effect on nitrogen fixation. Furthermore, a proteomic approach also suggested that the presence of ROS could be directly affecting nodule performance. Inhibition of the leaf photosynthetic apparatus made the nodules and leaves of plants dependent on root-derived carbon and nitrogen. Fourteen days after shoot removal, proteomic, metabolic and gas exchange analyses confirmed that nodule and leaf function were restored to control values. TSP content and isotopic analyses indicated that root-derived nitrogen was mobilised towards shoot development and more specifically towards the synthesis of Rubisco in the leaves.

\section{Acknowledgements}

This work has been funded in part by European research projects PERMED and OPTIMA and the Spanish National Research and Development Programme-European 
Regional Development Fund ERDF (AGL2011-30386-C02-01). IA was the recipient of a Ramon y Cajal research grant (Ministerio de Economia y Competitividad).

\section{References}

Aranjuelo I, Molero G, Erice G, Avice JC, Nogués S (2011) Plant physiology and proteomics reveals the leaf response to drought in alfalfa (Medicago sativa L.). $\mathrm{J}$ Exp Bot 62: 111-123.

Aranjuelo I, Tcherkez G, Molero G, Gilard F, Avice JC, Nogués S (2013). Concerted changes in $\mathrm{N}$ and $\mathrm{C}$ primary metabolism in alfalfa (Medicago sativa) under water restriction. J Exp Bot 64: 885-897.

Arrese-Igor C, Minchin FR, Gordon AJ, Nath AK (1997) Possible causes of the physiological decline in soybean nitrogen fixation in the presence of nitrate. J Exp Bot 48: 905-913.

Arrese-Igor C, Gonzalez EM, Gordon AJ, Minchin FR, Galvez L, Royuela M, Cabrerizo PM, Aparicio-Tejo PM (1999) Sucrose synthase and nodule nitrogen fixation under drought and other environmental stresses. Symb 27: 189-212.

Avice JC, Le Dily F, Goulas E, Noquet C, Meuriot F, Volenec JJ, Cunningham SM, Sors TG, Dhont C, Castonguay Y, Nadeau P, Bélanger G, Chalifour FC, Ourry A (2003) Vegetative storage proteins in overwintering storage organs of forage legumes: Roles and regulation. Can J Bot 81: 1198-1212.

Avice JC, Ourry A, Lemaire G, Boucaud J (1996) Nitrogen and carbon flows estimated by ${ }_{15} \mathrm{~N}$ and ${ }_{13} \mathrm{C}$ pulse-chase labeling during regrowth of Alfalfa. Plant Physiol 112: 281-290.

Avice JC, Ourry A, Lemaire G, Volenec JJ, Boucaud J (1997) Root protein and vegetative storage protein are key organic nutrients for alfalfa shoot regrowth. Crop Sci 37: 1187-1193.

Barber LD, Joern BC, Volenec JJ, Cunningham SM (1996) Supplemental nitrogen effects on alfalfa regrowth and nitrogen mobilization from roots. Crop Sci 36: 1217-1223.

Becana M, Matamoros MA, Udvardi M, Dalton DA (2010) Recent insights into antioxidant defenses of legume root nodules. New Phytol 188: 960-976.

Boucaud J, Bigot J (1989) Changes in the activities of nitrogen assimilation enzymes of Lolium perenne L. during regrowth after cutting. Plant Soil 114: 121-125. 
Bradford MM (1976) A rapid and sensitive method for the quantification of microgram quantities of protein utilizing the principles of protein-dye binding. An Biochem 72: 248-254.

Corre N, Bouchart V, Ourry A, Boucaud J (1996) Mobilization of nitrogen reserves during regrowth of defoliated Trifolium repens L. and identification of potential vegetative storage proteins. J Exp Bot 47: 1111-1118.

Dhont C, Castonguay Y, Nadeau P, Bélanger G, Chalifour FC (2002) Alfalfa root carbohydrates and regrowth potential in response to fall harvests. Crop Sci 42: 754-765.

Dhont C, Castonguay Y, Nadeau P, Bélanger G, Drapeau R, Laberge S, Avice JC, Chalifour FC (2006) Nitrogen reserves, spring regrowth and winter survival of fieldgrown alfalfa (Medicago sativa) defoliated in the autumn. Ann Bot 97: 109120.

Erice G, Sanz-Sáez A, Aranjuelo I, Irigoyen JJ, Aguirreolea J, Avice JC, Sánchez-Díaz M (2011). Photosynthesis, N2 fixation and taproot reserves during the cutting regrowth cycle of alfalfa under elevated $\mathrm{CO}_{2}$ and temperature. J Plant Physiol 168: 2007-2014.

Ethier GJ, Livingston NJ (2004) On the need to incorporate sensitivity to $\mathrm{CO}_{2}$ transfer conductance into the Farquhar-von Caemmerer-Berry leaf photosynthesis model. Plant, Cell Environ 27: 137-153.

Farquhar GD, von Caemmerer S, Berry JA (1980) A biochemical model of photosynthetic $\mathrm{CO}_{2}$ assimilation in leaves of $\mathrm{C}_{3}$ species. Planta 149: 78-90.

Gálvez L, González EM, Arrese-Igor C (2005) Evidence for carbon flux shortage and strong carbon/nitrogen interactions in pea nodules at early stages of water stress. J Exp Bot 56: 2551-2561.

Gramshaw D, Lowe KF, Lloyd DL (1993) Effect of cutting interval and winter dormancy on yield, persistence, nitrogen concentration, and root reserves of irrigated lucerne in the Queensland subtropics. Aust J Exp Agri 33: 847-854. 22

Hartwig UA, Heim I, Luscher A, Nosberger J (1994) The nitrogen-sink is involved in the regulation of nitrogenase activity in white clover after defoliation. Physiol Plant 92: 375-382.

Kim TH, Ourry A, Boucaud J, Lemaire G (1993) Partitioning of nitrogen derived from N2 fixation and reserves in nodulated Medicago sativa L. during regrowth. J Exp Bot 44: 555-562. 
King CA, Purcell LC (2005) Inhibition of $\mathrm{N}_{2}$ fixation in soybean is associated with elevated ureides and amino acids. Plant Physiol 137: 1389-1396.

Kouchi H, Yoneyama T (1986) Metabolism of ${ }^{13} \mathrm{C}$-labeled photosynthate in plant cytosol and bacteroids of root nodules of Glycine max L. Merr. Physiol Plant 68: 238-244.

Lodwig EM, Hosie AHF, Bourdès A, Findlay K, Allaway D, Karunakaran R, Downie JA, Poole PS (2003) Amino-acid cycling drives nitrogen fixation in the legumeRhizobium symbiosis. Nature 422: 722-726.

Long SP, Bernacchi CJ (2003) Gas exchange measurements, what can they tell us about the underlying limitations to photosynthesis? Procedures and sources of error. J Exp Bot 54: 2393-2401.

Marino D, González EM, Arrese-Igor C (2006) Drought effects on carbon and nitrogen metabolism of pea nodules can be mimicked by paraquat: evidence for the occurrence of two regulation pathways under oxidative stresses. J Exp Bot 57: 665-673.

Mechin V, Consoli L, Le Guilloux M, Damerval C (2003) An efficient solubilization buffer for plant proteins focused in immobilized pH gradients. Prot 3: 1299-1302.

Meuriot F, Avice J-, Simon J-, Laine P, Decau M-, Ourry A (2004) Influence of initial organic $\mathrm{N}$ reserves and residual leaf area on growth, $\mathrm{N}$ uptake, $\mathrm{N}$ partitioning and $\mathrm{N}$ storage in alfalfa (Medicago sativa) during post-cutting regrowth. Ann Bot 94: 311-321.

Minchin FR, Summerfield RJ, Hadley P, Roberts EH, Rawthorne S (1981) Carbon and nitrogen nutrition of nodulated roots of grain legumes. Plant Cell Environ 4, 5-26.

Molero G, Aranjuelo I, Teixidor P, Araus JL, Nogués S (2011) Measurement of ${ }^{13} \mathrm{C}$ and ${ }^{15} \mathrm{~N}$ isotope labeling by gas chromatography/combustion/isotope ratio mass spectrometry to study amino acid fluxes in a plant-microbe symbiotic association. Rapid Comm Mass Spectr 25: 599-607.

Molero G, Tcherkez G, Araus JL, Nogués S, Aranjuelo I (2014) On the relationship between $\mathrm{C}$ and $\mathrm{N}$ fixation and amino acid synthesis in nodulated alfalfa (Medicago sativa L.). Funct Plant Biol (in press)

Naya L, Ladrera R, Ramos J, González EM, Arrese-Igor C, Minchin FR, Becana M (2007) The response of carbon metabolism and antioxidant defenses of alfalfa nodules to drought stress and to the subsequent recovery of plants. Plant Physiol 144: 1104- 1114. 
Nogués S, Tcherkez G, Cornic G, Ghashghaie J (2004) Respiratory carbon metabolism following illumination in intact French bean leaves using (13)C/(12)C isotope labeling. Plant Physiol 136: 3245-3254.

Ourry A, Kim Tae Hwan, Boucaud J (1994) Nitrogen reserve mobilization during regrowth of Medicago sativa L. Relationships between availability and regrowth yield. Plant Physiol 105: 831-837.

Pembleton KG, Volenec JJ, Rawnsley RP, Donaghy DJ (2010) Partitioning of taproot constituents and crown bud development are affected by water deficit in regrowing alfalfa (Medicago sativa L.). Crop Sci 50: 989-999.

Pons TL, Flexas J, Von Caemmerer S, Evans JR, Genty B, Ribas-Carbo M, Brugnoli E (2009) Estimating mesophyll conductance to $\mathrm{CO}_{2}$ : Methodology, potential errors, and recommendations. J Exp Bot 60: 2217-2234.

Prell J, Poole P (2006) Metabolic changes of rhizobia in legume nodules. Trends Micr 14: $161-168$.

Radutoiu S. Madsen LH, Madsen EB, Felle HH, Umehara Y, Gronlund M, Sato S, Nakamura Y, Tabata S, Sandal N, Stougaard J (2003) Plant recognition of symbiotic bacteria requires two LysM receptor-like kinases. Nature 425: 585-592.

Rubio MC, González EM, Minchin FR, Webb KJ, Arrese-Igor C, Ramos J, Becana M (2002) Effects of water stress on antioxidant enzymes of leaves and nodules of transgenic alfalfa overexpressing superoxide dismutases. Physiol Plant 115: 531540.

Schulze J (2004) How are nitrogen fixation rates regulated in legumes? J Plant Nutr Soil Sci 167: 125-137.

Serraj R, Sinclair TR, Allen LH (1998) Soybean nodulation and $\mathrm{N}_{2}$ fixation response to drought under carbon dioxide enrichment. Plant Cell Environ 21: 491-500.

Serraj R, Allen LH, Sinclair TR (1999) Soybean leaf growth and gas exchange response to drought under carbon dioxide enrichment. Glob Chan Biol 5: 283-291.

Serraj R, Vadez V, Sinclair TR (2001) Feedback regulation of symbiotic $\mathrm{N}_{2}$ fixation under drought stress. Agronomie 21: 621-626.

Streeter JG (1987). Carbohydrate, organic acid, and amino acid composition of bacteroids and cytosol from soybean nodules. Plant Physiol 85: 768-773.

Summerfield RJ, Minchin FR, Wien HC (1979) Screening soyabean and cowpea. An improved strategy. World Crops 31: 21-23. 
Ta TC, Macdowall FDH, Faris MA (1990) Utilization of carbon and nitrogen reserves of alfalfa roots in supporting N2-fixation and shoot regrowth. Plant and Soil 127: 231- 236.

Udvardi MK, Day DA (1997) Metabolite transport across symbiotic membranes of legume nodules. Ann Rev Plant Biol 48: 493-523.

Vance CP, Heichel GH, Barnes DK, Bryan JW, Johnson LE (1979) Nitrogen-fixation development, and vegetative regrowth of alfalfa (Medicago sativa L.) following harvest. Plant Physiol 64: 1-8.

Volenec JJ, Ourry A, Joern BC (1996) A role for nitrogen reserves in forage regrowth and stress tolerance. Physiol Plant 97: 185-193.

von Caemmerer S, Farquhar GD (1981) Some relationships between the biochemistry of photosynthesis and the gas exchange of leaves. Planta 153: 376-387.

Yemm EW, Cocking EC (1955) The determination of amino-acids with ninhydrin. Analyst 80: 209-213. 